\title{
Effect of coconut oil, milk powder on the viscosity and hardness of mixtures of cocoa powder and cocoa butter
}

\author{
Uyen N. H. Truong, Giang T. Tran, \& Bach T. Nguyen*
}

Faculty of Food Technology, Nha Trang University, Nha Trang, Vietnam

\author{
ARTICLE INFO \\ Research Paper \\ Received: July 18, 2018 \\ Revised: March 02, 2019 \\ Accepted: April 02, 2019 \\ Keywords \\ Cocoa powder/cocoa butter \\ Coconut oil \\ Hardness \\ Milk powder \\ Viscosity \\ ${ }^{*}$ Corresponding author \\ Nguyen Trong Bach \\ Email: ntbachnt@ntu.edu.vn
}

ABSTRACT

The effects of changing in composition and adding of coconut oil and milk powder on physical states and rheological properties of cocoa powder/cocoa butter mixtures were investigated. The aim of this study is to keep the product quality at the right temperature and then consumer's acceptance. The viscosity, hardness and the solidification temperature of cocoa powder/cocoa butter mixtures reduced when cocoa butter content increased or cocoa butter was replaced by coconut oil, or cocoa powder was replaced by milk powder. The viscosity $\left(\right.$ at $31^{\circ} \mathrm{C}$ and $50^{\circ} \mathrm{C}$ ) significantly decreased in accordance with an increase in cocoa butter (from 40 to $50 \%$ ), addition of coconut oils (from 10 to $20 \%$ ) and replacement of cocoa powder by milk powder (from 5 to $10 \%$ ) by weight. The cutting and breaking hardness of mixtures (at $10^{\circ} \mathrm{C}$ and $20^{\circ} \mathrm{C}$ ) decreased sharply when the cocoa butter content was more than $50 \%$ of the mixture by weight. The solidification temperature of mixtures decreased from $24^{\circ} \mathrm{C}$ to $20^{\circ} \mathrm{C}$ when the coconut oil ratio increased from $20 \%$ to $40 \%$ of mixture weight.

Cited as: Truong, U. N. H., Tran, G. T., \& Nguyen, B. T. (2019). Effect of coconut oil, milk powder on the viscosity and hardness of mixtures of cocoa powder and cocoa butter. The Journal of Agriculture and Development 18(4), 70-80. 


\title{
Ảnh hưởng của dầu dừa, sữa bột đến độ nhớt và độ cứng của hỗn hợp bột cacao/bơ cacao
}

\author{
Trương Nữ Hạ Uyên, Trần Thanh Giang \& Nguyễn Trọng Bách* \\ Khoa Công nghệ Thực Phẩm, Trường Đại học Nha Trang, Nha Trang
}

\section{THÔNG TIN BÀI BÁO}

Bài báo khoa học

Ngày nhận: 18/07/2018

Ngày chỉnh sửa: 02/03/2019

Ngày chấp nhận: 02/04/2019

\section{Từ khóa}

Bột cacao/bơ cacao

Dầu dừa

Độ cứng

Độ nhớt

Sữa bột

\section{*Tác giả liên hệ}

Nguyễn Trọng Bách

Email: ntbachnt@ntu.edu.vn

\section{TÓM TẮT}

Trạng thái và tính chất lưu biến của hỗn hợp bột cacao/bơ cacao được khảo sát khi thay đổi thành phần và tỉ lệ của hỗn hợp bằng cách bổ sung dầu dừa hoặc sữa bột vào hỗn hợp làm cơ sở cho việc chọn tỉ lệ dầu dừa hoặc sữa bột bổ sung vào sản phẩm sôcôla, hướng đến việc giữ chất lượng sản phẩm ở điều kiện nhiệt độ phù hợp, đem sản phẩm đến gần với người tiêu dùng hơn. Độ nhớt, độ cứng và nhiệt độ kết tinh hóa rắn của hỗn hợp bột cacao/bơ cacao giảm khi tăng tỉ lệ bơ cacao hoặc dùng dầu dừa thay thế bơ cacao hoặc dùng sữa bột thay thế bột cacao. Độ nhớt $\left(\right.$ ơ $^{\circ} 31^{\circ} \mathrm{C}$ và $50^{\circ} \mathrm{C}$ ) giảm mạnh khi tỉ lệ bơ cacao tăng từ $40 \%$ đến $50 \%$ khối lượng hỗn hợp, hoặc khi dùng dầu dừa từ 10\% đến $20 \%$ khối lượng hỗn hợp hoặc dùng sữa bột từ $5 \%$ đến $10 \%$ khối lượng hỗn hợp. Độ cứng cắt và độ cứng vỡ của hỗn hợp (ở $10^{\circ} \mathrm{C}$ và $20^{\circ} \mathrm{C}$ ) giảm mạnh khi tî̉ lệ bơ cacao tăng hơn $50 \%$ khối lượng hỗn hợp. Nếu thay thế quá nhiều bột cacao bằng sữa bột (40 - 60\% khối lượng hỗn hợp) sẽ làm cấu trúc của sôcôla không chặt chẽ, khi cắt hoặc làm vỡ xuất hiện nhiều vụn nhỏ do chất rắn không được áo ngoài tốt bởi bơ cacao. Nhiệt độ kết tinh hóa rắn của hỗn hợp giảm từ $24^{0} \mathrm{C}$ xuống $20^{\circ} \mathrm{C}$ khi tăng tỷ lệ dầu dừa từ $20 \%$ đến $40 \%$ khối lượng hỗn hợp.

\section{1. Đặt Vấn Đề}

Sôcôla là một trong số những sản phẩm có giá trị lớn từ cây cacao, được nhiều người ưa chuộng và sử dụng ngày càng nhiều. Tuy nhiên giá thành sôcôla còn khá cao và khi bảo quản ngoài thị trường vẫn còn khá khó khăn, cần phải được bảo quản ở nhiệt độ thấp, nếu không rất dễ tan chảy. Thành phần chính của sôcôla bao gồm bơ cacao và bột cacao (Afoakwa \& ctv., 2007), việc nghiên cứu tính chất của hỗn hợp các nguyên liệu sẽ giúp hiểu rõ về cấu trúc, mức độ chảy thông qua độ nhớt hỗn hợp sôcôla lỏng để thiết kế quá trình bơm đẩy, vận chuyển, rót khuôn,...; đồng thời tỷ lệ các thành phần cũng ảnh hưởng đến độ cứng của khối sôcôla sau kêt tinh. Trong hai thành phần chính của sôcôla thì bơ cacao là một trong những loại có giá trị nhất trong số các loại chất béo nhiệt đới (Afoakwa \& ctv., 2007). Tuy nhiên trong những năm gần đây, sản lượng bơ cacao bị hạn chế bởi điều kiện canh tác khó khăn và sâu bệnh trong khi nhu cầu bơ cacao tăng cao ở các nước đang phát triển và giá cacao thế giới ngày càng tăng (Afoakwa \& ctv., 2007). Vì lý do đó, việc nghiên cứu thành phần thay thế bơ cacao giúp nhà sản xuất giảm được chi phí nguyên liệu chính, tăng giá trị dinh dưỡng, hài hòa lợi ích kinh tế nhưng vẫn đáp ứng được các điều kiện bảo quản, sử dụng sản phẩm trong thực tế là điều cần thiết.

Trên thế giới đã có những nghiên cứu về sự ảnh hưởng của một số loại dầu như dầu cọ, dầu dừa (Limbardo \& ctv., 2017) đến nhiệt độ tan chảy của hỗn hợp bơ cacao và dầu dừa; sự ảnh hưởng của nguồn chất béo trong sôcôla (Timms, 1980; Full \& ctv., 1996; Gabriele \& ctv., 2008); ảnh hưởng của loại sữa bột (Liang \& Hartel, 2004; Ačkar \& ctv., 2015) hay tính chất của sôcôla đen/trắng và sôcôla sữa (Briggs \& Wang, 2004; Afoakwa \& ctv., 2008; Ardakani \& ctv., 2014) cũng được nghiên cứu. Tuy nhiên, ở Việt Nam chưa có những nghiên cứu chuyên sâu nào được 
công bố về sự hình thành trạng thái, tính chất lưu biến của hỗn hợp bột cacao/bơ cacao có nguồn gốc tại Việt Nam hay hỗn hợp của chúng khi có bổ sung dầu dừa hoặc sữa bột. Trong nghiên cứu này, dầu dừa được khảo sát thay thế bơ cacao do dầu dừa là một chất béo được sản xuất trong nước có sản lượng lớn. Bên cạnh đó, việc khảo sát bổ sung sữa bột thay thế một phần bột cacao giúp sản phẩm sôcôla tăng giá trị dinh dưỡng. Kết quả nghiên cứu sẽ làm cơ sở cho các nghiên cứu tiếp theo để tối ưu các thành phần trong sản xuất sôcôla như lượng dầu dừa và sữa bột, việc hiểu được các tính chất đặc trưng của sôcôla mà từ đó nhà sản xuất tìm được qui trình sản xuất tạo sản phẩm tối ưu, phù hợp với từng vùng địa lý khác nhau cho các loại sản phẩm sôcôla đồng thời định hướng người tiêu dùng sử dụng, bao quản sản phẩm hợp lý hơn.

\section{Vật Liệu và Phương Pháp Nghiên Cứu}

\subsection{Vật liệu}

Bột cacao, bơ ca cao là sản phẩm của Công ty TNHH Cacao Nam Trường Sơn, Đắklăk. Lô sản phẩm sử dụng được sản xuất ngày $16 / 01 / 2017$ và có hạn sử dụng ngày 16/07/2018.

Dầu dừa được sản xuất ngày 13/03/2017 tại Công ty Cổ phần dầu thực vật Tường An và có hạn sử dụng ngày 13/03/2019. Sữa bột nguyên kem Dutch Lady (19\% protein; 22,8\% chất béo; $48,4 \%$ cacbonhydrat; $3,5 \%$ nước và $6,3 \%$ thành phần khác) của Công ty TNHH Friesland Campina, thuộc lô sản xuất ngày $03 / 10 / 2016$ và có hạn sử dụng ngày 03/04/2018.

\subsection{Chuẩn bị mẫu}

Có 03 nhóm mẫu được khảo sát: Nhóm mẫu nguyên chất ( $\mathrm{M}$, gồm có bơ cacao và bột cacao); mẫu nghiên cứu ảnh hưởng của dầu dừa $(\mathrm{MCO}$, cố định bột cacao $50 \%, 50 \%$ còn lại là chất béo bao gồm bơ cacao và dầu dừa); và mẫu nghiên cứu ảnh hưởng của sữa bột (MMP, cố định lượng bơ cacao $30 \%, 70 \%$ còn lại là bột cacao và sữa bột).

Chuẩn bị $100 \mathrm{~g}$ mỗi mẫu với tỉ lệ các thành phần theo Bảng 1. Khuấy trộn đều hỗn hợp, gia nhiệt ở $50 \pm 2^{0} \mathrm{C}$ trong 15 phút và đồng hóa bằng thiết bị khuấy trộn Philips blender HR2115 (thực hiện 5 lần, mỗi lần 30 giây). Sau đó rót vào các ống nghiệm nắp kín (đường kính $1,5 \mathrm{~cm}$, cao 12 $\mathrm{cm}$ ), đặt trong bể ổn nhiệt TC-502 (Brookfield,
Hoa Kỳ) tại các nhiệt độ khác nhau để tiến hành quan sát trạng thái lỏng-rắn của từng mẫu.

Bảng 1. Tỷ lệ \% khối lượng các thành phần trong hỗn hợp

\begin{tabular}{ccc}
\hline $\begin{array}{c}\text { Bơ cacao/ } \\
\text { bột cacao } \\
(\mathrm{M})\end{array}$ & $\begin{array}{c}\text { Bơ cacao/ } \\
\text { dầu dừa/ } \\
\text { bột cacao } \\
(\mathrm{MCO})\end{array}$ & $\begin{array}{c}\text { Bơ cacao/ } \\
\text { bột cacao/ } \\
\text { sữa bột } \\
(\mathrm{MMP})\end{array}$ \\
\hline $30 / 70$ & $50 / 0 / 50$ & $30 / 65 / 5$ \\
$40 / 60$ & $40 / 10 / 50$ & $30 / 60 / 10$ \\
$50 / 50$ & $30 / 20 / 50$ & $30 / 50 / 20$ \\
$60 / 40$ & $20 / 30 / 50$ & $30 / 40 / 30$ \\
$70 / 30$ & $10 / 40 / 50$ & $30 / 30 / 40$ \\
$80 / 20$ & $0 / 50 / 50$ & $30 / 20 / 50$ \\
- & - & $30 / 10 / 60$ \\
\hline
\end{tabular}

Đối với việc xác định độ nhớt của hỗn hợp: Sau khi quan sát trạng thái, tiến hành đo độ nhớt các mẫu $\mathrm{M}, \mathrm{MCO}, \mathrm{MMP}$ ở nhiệt độ tan chảy $\left(50^{\circ} \mathrm{C}\right)$ và nhiệt độ rót khuôn $\left(31^{\circ} \mathrm{C}\right)$.

Đối với việc khảo sát sự thay đổi độ cứng cắt và độ cứng vỡ của mẫu M, MCO, MMP: Tiến hành rót khuôn ( dài $\times$ rộng $=30 \times 20 \mathrm{~mm}$ ) hỗn hợp sau đồng hóa với độ dày $5 \mathrm{~mm}$ rồi giữ lạnh ở các nhiệt độ $\left(5^{0} \mathrm{C}, 10^{0} \mathrm{C}, 20^{\circ} \mathrm{C}\right)$ trong 15 giờ. Mẫu sau khi được ổn định trang thái nhanh chóng được đo độ cứng vơ/độ cứng cắt ở nhiệt độ phòng ổn định tại $25^{\circ} \mathrm{C}$.

\subsection{Phương pháp nghiên cứu và xử lý số liệu}

\subsubsection{Phương pháp quan sát}

Hỗn hợp sau đồng hóa được rót vào trong ống nghiệm đậy kín nắp để tiến hành quan sát. Mẫu được đặt trong bể ổn nhiệt TC-502 (Brookfield, Hoa Kỳ) ở $50^{\circ} \mathrm{C}$, sau đó tiến hành giảm dần nhiệt độ xuống $5^{0} \mathrm{C}$ theo từng nấc nhiệt độ $\left(40^{\circ} \mathrm{C}, 35\right.$ $\left.-20^{0} \mathrm{C}, 15^{0} \mathrm{C}, 10^{\circ} \mathrm{C}, 5^{\circ} \mathrm{C}\right)$, tại mỗi nhiệt độ giữ nhiệt trong 45 phút để ổn định cấu trúc rồi quan sát. Lấy ống đựng mẫu ra và nghiêng ống nếu không thấy mẫu chảy thì coi đó là trạng thái đã kết tinh hóa rắn. Ghi nhận trạng thái, nhiệt độ hóa rắn kết tinh của hỗn hợp.

\subsubsection{Phương pháp phân tích lưu biến}

Đo độ nhớt: Xác định bằng máy đo độ nhớt Brookfield Viscometer LVDV I - Prime (Hoa Kỳ). Mẫu lỏng sau khi được đồng hóa được rót vào ống chứa mẫu, đặt vào bể ổn nhiệt của máy 
Brookfield tại nhiệt độ đo $\left(50^{\circ} \mathrm{C}\right.$ hoặc $\left.31^{\circ} \mathrm{C}\right)$ trong 20 phút, khi nhiệt độ mẫu ổn định tiến hành đo mẫu với các đầu đo thích hợp (số 63 hoặc 64) ở tốc độ đo 100 vòng/phút.

Đo độ cứng: Độ cứng vỡ (Fracturability) và độ cứng cắt (Hardness) là lực mà khi nén ép tại đó làm cho mẫu rắn bị vỡ ra hay lực lớn nhất cần thiết để cắt đứt mẫu rắn (Mochizuki, 2001). Độ cứng vỡ và độ cứng cắt của mẫu rắn $(30 \times 20 \mathrm{~mm})$ có chiều dày $5 \mathrm{~mm}$ được xác định bằng thiết bị đo lưu biến Sun Scientific Rheometer CR-500DX (Nhật Bản) với các đầu đo tương ứng là đầu đo số 3 (đường kính 10 mm, xem Hình 1 (trái)) và đầu đo số 10 (dạng phẳng, xem Hình 1 (phải)). Mẫu sau khi được giữ để cố định cấu trúc ở 5,10 hay $20^{0}$ (15 giờ) sẽ được đem đo nhanh tại nhiệt độ phòng bằng chế độ nén (compression test) có tốc độ di chuyển của đầu đo khi nén là $1 \mathrm{~mm} /$ giây.
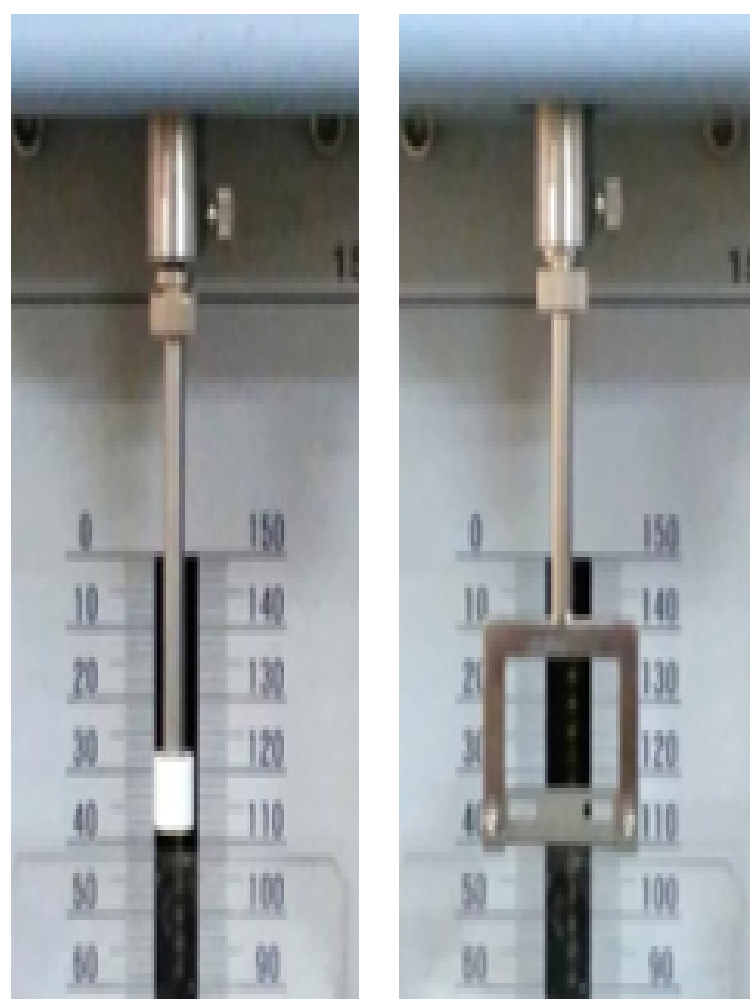

Hình 1. Đầu đo số 3 (trái) và số 10 (phải).

\subsubsection{Phương pháp xử lý số liệu}

Các thí nghiệm được thực hiện 3 lần, kết quả thu được là giá trị trung bình của các lần đo. Xử lý số liệu và vẽ biểu đồ bằng phần mềm Origin 8.5.1 (bản quyền được cung cấp bởi phòng thí nghiệm PCI thuộc viện IMMM, Cộng hòa Pháp).

\section{Kết Quả và Thảo Luận}

\section{1. Ảnh hưởng của tỷ lệ bơ cacao/bột cacao đến trạng thái, độ nhớt và độ cứng của hỗn hợp}

Trạng thái của hỗn hợp bơ cacao và bột cacao (M) với các tỷ lệ khác nhau tại các nhiệt độ được biễu diễn ở Hình 2. Sự kết tinh hóa rắn của hỗn hợp được quyết định bởi sự có mặt của bơ cacao (Limbardo \& ctv., 2017), nhiệt độ kết tinh có xu hướng tăng dần với các mẫu có tỷ lệ bơ cacao thấp $(\leq 50 \%)$, khoảng từ $24^{0} \mathrm{C}$ đến $29^{\circ} \mathrm{C}$. Hỗn hợp $(\mathrm{M})$ khi đồng hóa sẽ xảy ra hiện tượng bơ caca tan chảy và bao phủ ngoài các hạt bột cacao. Vì vậy khi hàm lượng bơ cacao càng thấp thì lớp áo phủ ngoài các hạt bột cacao càng mỏng và chúng nhanh chóng kết tinh và sớm hình thành các tương tác giữa các hạt bột cacao (Glicerina \& ctv., 2016) khi nhiệt độ giảm. Hàm lượng bột cacao dưới $50 \%$ thì nhiệt độ kết tinh của hỗn hợp ổn định ở $23^{0} \mathrm{C}$ do tại những tỷ lệ này lượng bơ cacao đã bao phủ kín và bão hòa nên nhiệt độ kết tinh chỉ phụ thuộc vào sự có mặt của chất béo (bơ cacao) mà không phụ thuộc vào các hạt bột cacao nũa.

Độ nhớt của mẫu có tỷ lệ bơ cacao/bột cacao khác nhau ở $50^{\circ} \mathrm{C}$ và $31^{0} \mathrm{C}$ được trình bày tại Hình 3. Khi tăng tỷ lệ bơ cacao thì độ nhớt giảm, điều này là do bột cacao được bao phủ bởi lớp bơ cacao càng nhiều và chúng phân tán trong pha chất béo do đó giảm khả năng kháng dòng chảy, hỗn hợp sẽ lỏng hơn và độ nhớt giảm (Chevalley, 1975; Afoakwa \& ctv., 2009; Glicerina \& ctv., 2016). Đồng thời, theo quan hệ giữa độ nhớt và nhiệt độ của Arrhenius thì nhiệt độ càng tăng độ nhớt càng giảm (Gao \& ctv., 2015), do đó độ nhớt của hỗn hợp ở nhiệt độ $31^{\circ} \mathrm{C}$ cao hơn so với ở nhiệt độ $50^{\circ} \mathrm{C}$. Mặt khác, theo thuyết chuyển động nhiệt Brown, nhiệt độ càng tăng thì động năng các phân tử càng lớn và vận tốc chuyển động của phân tử càng cao. Vì vậy, ở $31^{0} \mathrm{C}$ động năng của các phân tử trong hỗn hợp thấp hơn, tốc độ chảy chậm hơn và độ nhớt trung bình cao hơn so với hỗn hợp ở $50^{0} \mathrm{C}$, tuy nhiên sự khác biệt giá trị độ nhớt giữa hai nhiệt độ này không có ý nghĩa thống kê (kiểm định giá trị trung bình hai mẫu độc lập T-test trong mềm SPSS, phiên bản 17.0).

Hình $4 \mathrm{a}$ và $4 \mathrm{~b}$ biễu diễn độ cứng cắt và độ cứng vỡ của mẫu có chiều dày $5 \mathrm{~mm}$ với tỷ lệ các thành phần khác nhau tại nhiệt độ làm lạnh $5^{0} \mathrm{C}, 10^{\circ} \mathrm{C}$ và $20^{\circ} \mathrm{C}$. Độ cứng cắt và độ cứng vỡ giảm khi tăng 


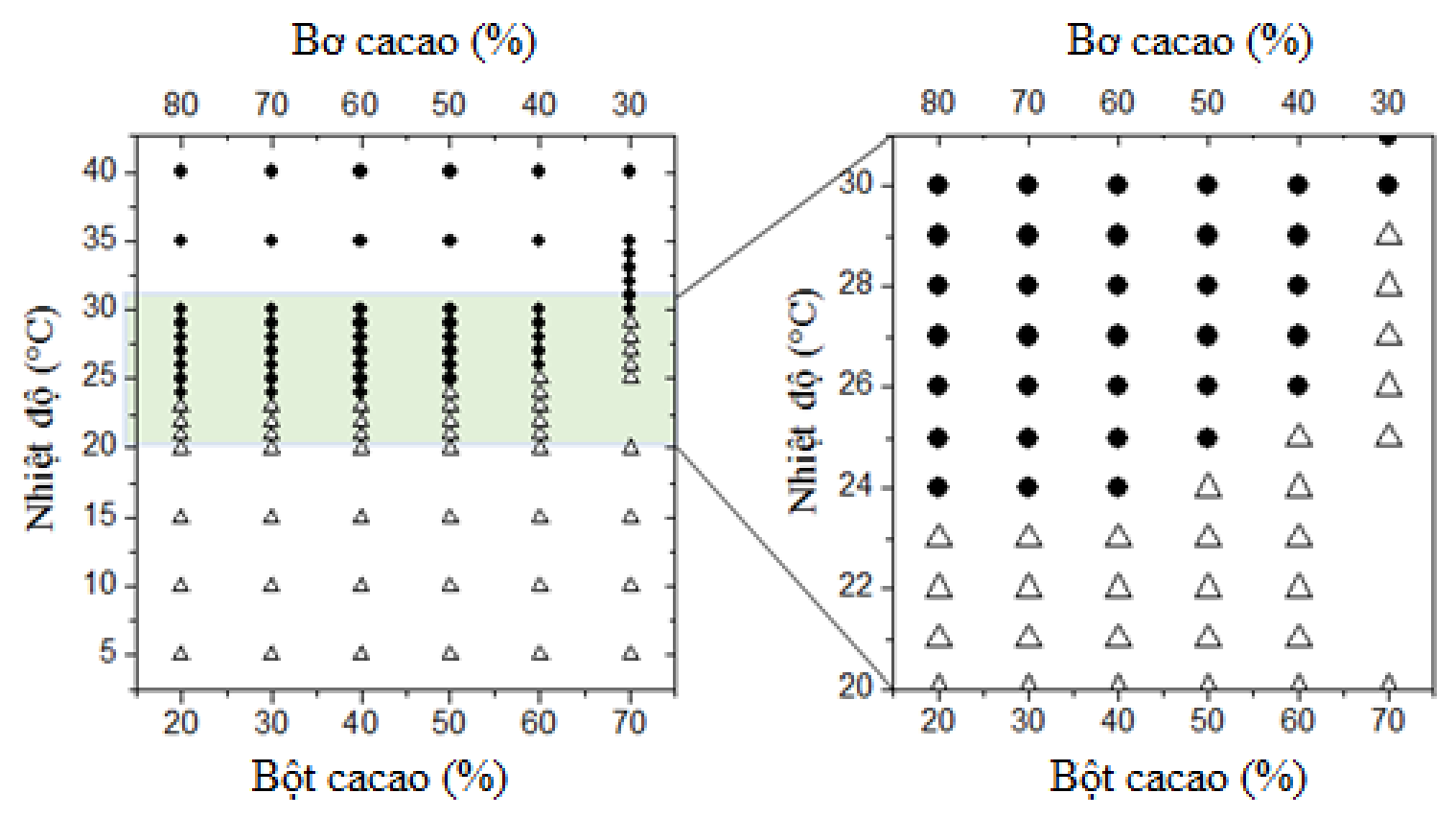

Hình 2. Trạng thái lỏng $(\bullet)$ - rắn $(\Delta)$ của hỗn hợp bơ cacao/bột cacao theo nhiệt độ.

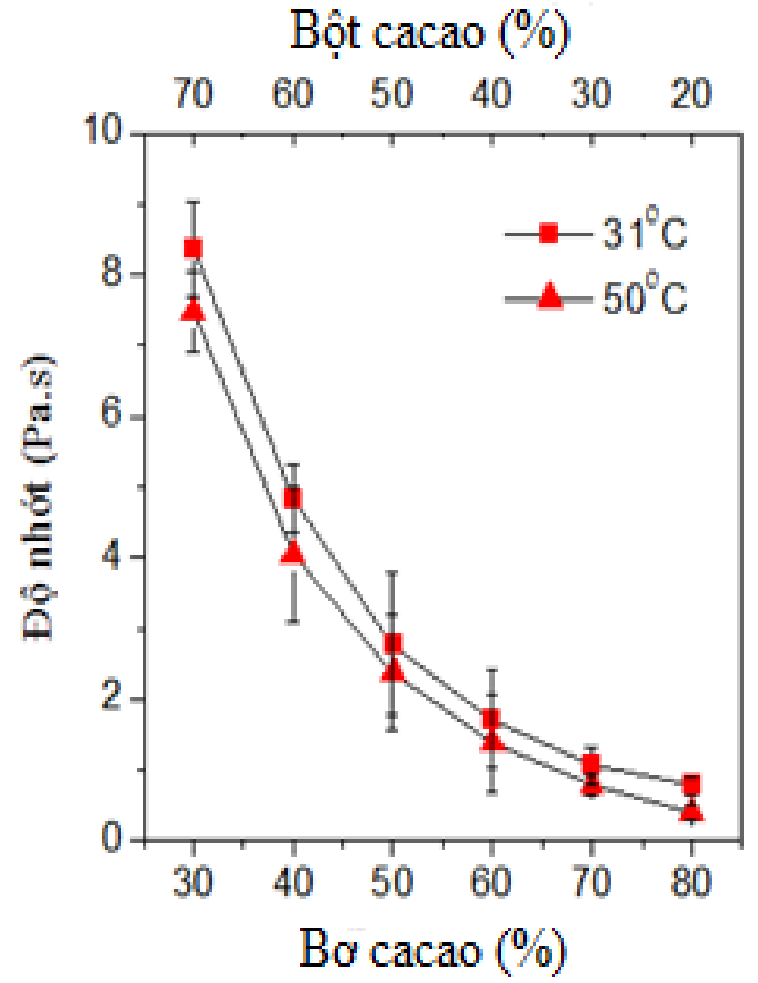

Hình 3. Ảnh hưởng của lệ bơ cacao/bột cacao đến độ nhớt. tỷ lệ bơ cacao trong khối mẫu hay tăng nhiệt độ làm lạnh. Hỗn hợp có tỷ lệ bơ cacao lớn, bơ sẽ bao phủ bột cacao nhiều hơn, tương tác giữa các hạt cacao với nhau sẽ giảm (Glicerina \& ctv., 2016) nên khi đưa ra môi trường không khí bên ngoài hỗn hợp sẽ nhanh tan chảy hơn, có độ cứng khi đo lực cắt và lực ép vỡ thấp hơn các mẫu có tỷ lệ bơ cacao thấp hơn.

Từ kết quả thể hiện trên Hình 4, mẫu được kết tinh ở nhiệt độ càng thấp thì cần lực phá vỡ cấu trúc càng lớn. Tại nhiệt độ làm lạnh $10^{0} \mathrm{C}$ và $20^{\circ} \mathrm{C}$, độ cứng cắt và độ cứng vỡ của mẫu phụ thuộc vào tỷ lệ các thành phần phối trộn: độ cứng cắt giảm mạnh khi hàm lượng bơ cacao lớn hơn $60 \%$ và độ cứng vỡ giảm mạnh khi hàm lượng bơ cacao lớn hơn $50 \%$. Tuy nhiên ở $5{ }^{0} \mathrm{C}$, độ cứng ít thay đổi khi thay đổi tỷ lệ các thành phần, điều này chứng tỏ khi nhiệt độ càng thấp thì bơ cacao càng nhanh kết tinh, các mầm tinh thể xuất hiện nhanh hơn và nhiều hơn tạo khối ổn định và vững chắc (Awad \& Marangoni, 2006). Ở nhiệt độ cao hơn, ảnh hưởng của tỷ lệ các thành phần rõ ràng hơn đặc biệt tại $20^{\circ} \mathrm{C}$, các tinh thể kết tinh nhỏ hơn có năng lượng tự do thấp hơn nên có sự dịch chuyển về hướng có tinh thể kêt tinh lớn hơn (Awad \& Marangoni, 2006), vì vậy lực cắt giảm và độ cứng vỡ thấp vì khi đó mật độ tinh thể chất béo giảm, các không gian mở sẽ 

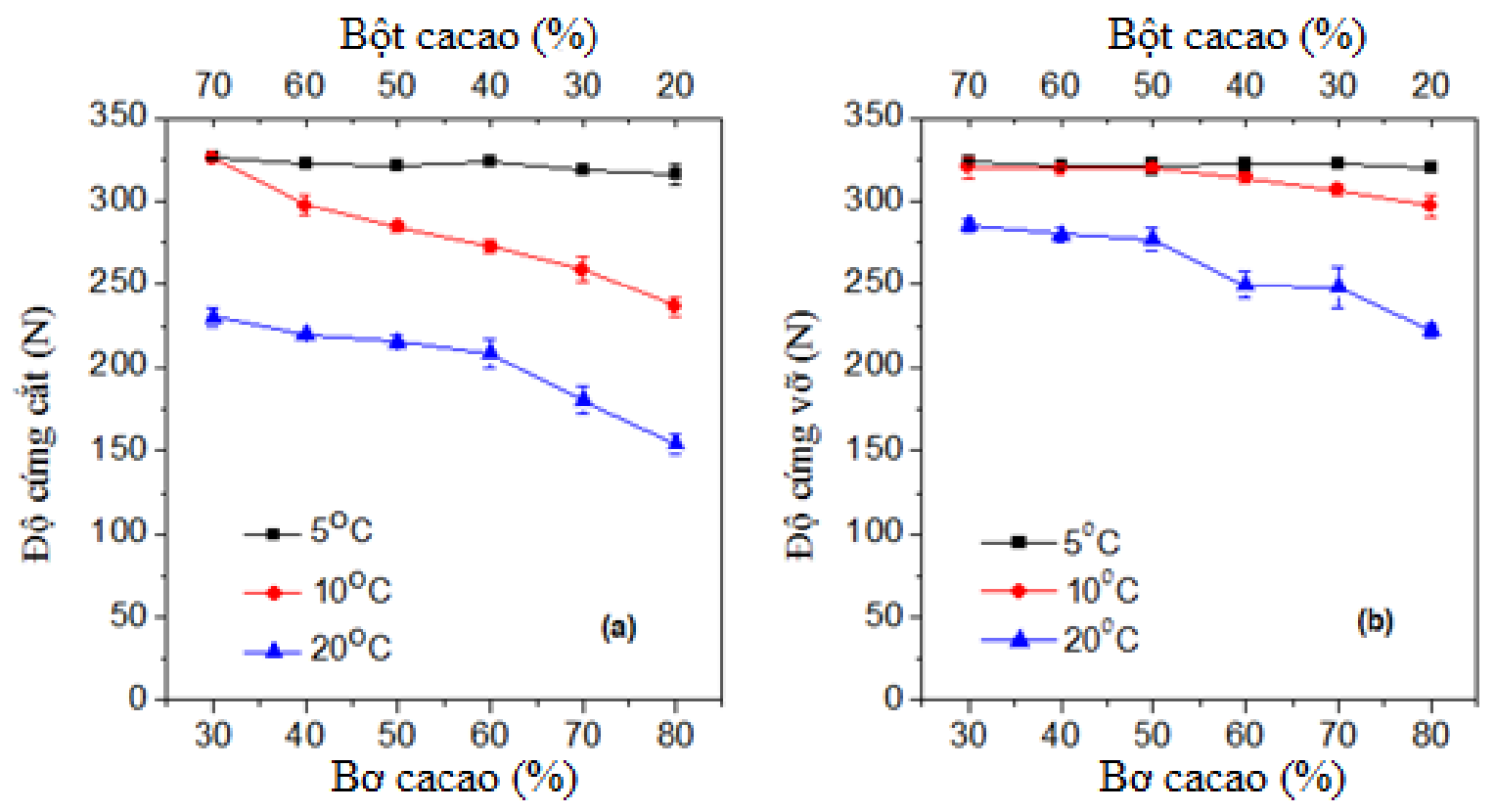

Hình 4. Độ cứng - cắt (a) và độ cứng - vỡ $(\mathrm{b})$ của mẫu $(\mathrm{M})$ dày 5 mm.
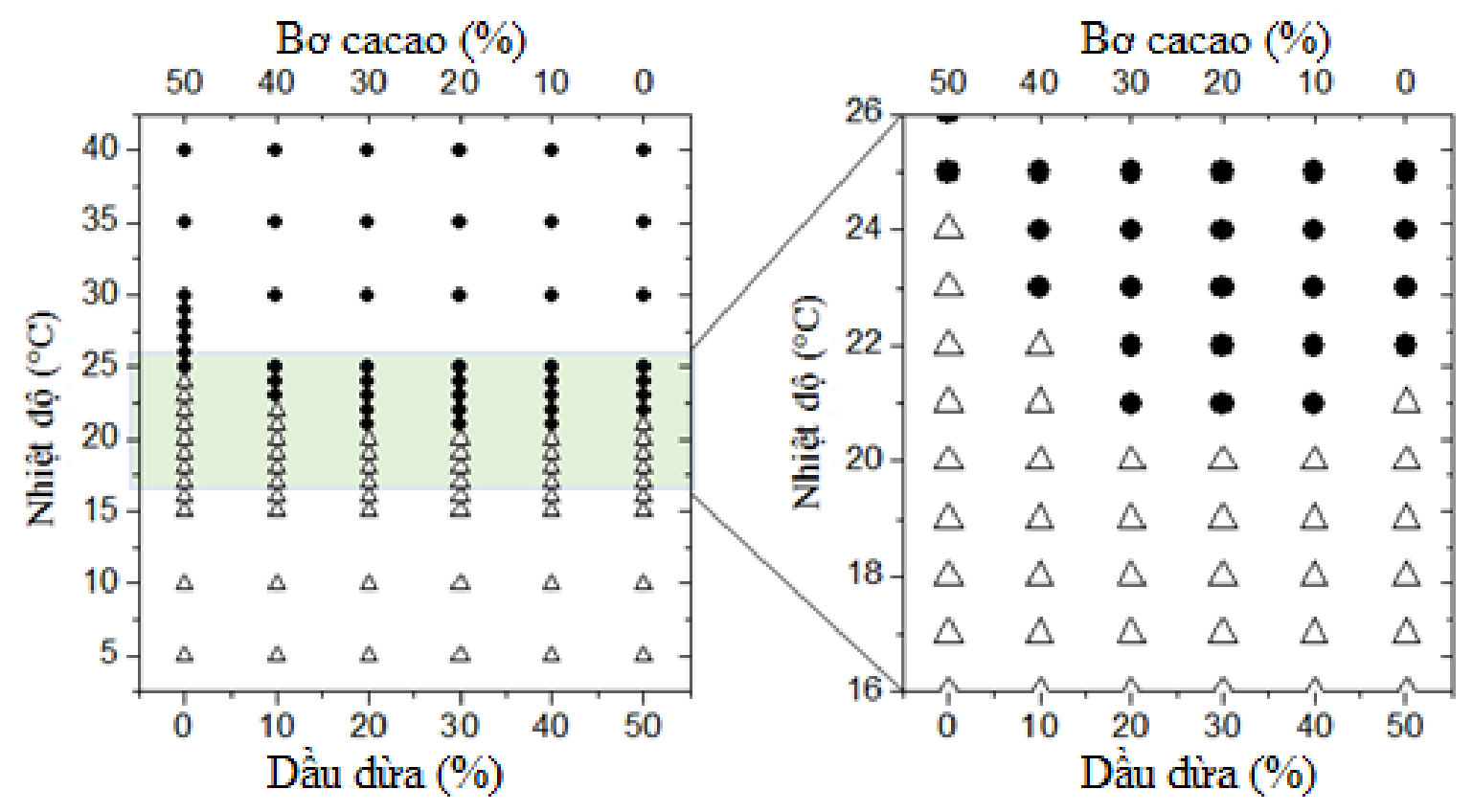

Hình 5. Trạng thái lỏng $(\bullet)$ - rắn $(\Delta)$ của hỗn hợp bơ cacao/bột cacao có bổ sung dầu dừa.

được điền đầy bởi bơ cacao nên mẫu dễ bị làm mềm khi tăng nhiệt độ (Afoakwa \& ctv., 2009). Đồng thời như giải thích trên thì ảnh hưởng của mật độ bột cacao đóng vai trò quan trọng, nên khi tăng hàm lượng bơ cacao tương tác giữa các hạt bột cacao với nhau sẽ yếu đi (Glicerina \& ctv., 2016) dẫn đến độ cứng cắt và độ cứng vỡ giảm. Sự ảnh hưởng của chiều dày mẫu cũng được khảo sát và kết quả cho thấy với chiều dày $10 \mathrm{~mm}$, ảnh hưởng của tỷ lệ các thành phần, nhiệt độ cũng có 
xu hướng biến đổi tương tự như mẫu có chiều dày 5 mm (kết quả không được trình bày).

\section{2. Ảnh hưởng của dầu dừa đến trạng thái, độ nhớt và độ cứng của hỗn hợp}

Trạng thái của mẫu (MCO) có chứa dầu dừa thay thế một phần bơ cacao tại các nhiệt độ được thể hiện ở Hình 5. Khi thay thế bơ cacao bằng dầu dừa từ 0 - $100 \%$ tổng lượng chất béo trong hỗn hợp (50\%), nhiệt độ kết tinh hóa rắn giảm dần từ $24^{\circ} \mathrm{C}$ đến $20^{\circ} \mathrm{C}$ và ổn định ở nhiệt độ này khi tăng tỷ lệ dầu dừa hơn $20 \%$ khối lượng hỗn hợp.

Điều này có thể được giải thích dựa trên hiệu ứng "eutecti". Hỗn hợp "eutecti" được định nghĩa là một hỗn hợp của hai hoặc nhiều thành phần thường không tương tác để tạo thành một hỗn hợp mới, nhưng theo một tỷ lệ nào đó, ức chế quá trình kết tinh của nhau dẫn đến một hệ có điểm nóng chảy thấp hơn một trong hai thành phần (Gala \& ctv., 2013). Mặc dù hai thành phần bơ cacao và dầu dừa có tính chất tương tự nhưng khi phối trộn với nhau chúng không tương thích (Afoakwa \& ctv., 2007) đã tạo nên một hỗn hợp "eutecti" làm nhiệt độ kết kinh giảm xuống so với hỗn hợp chỉ có bơ cacao. Chất béo bão hòa trong hỗn hợp sẽ quyết định đến nhiệt độ tan chảy, hay kết tinh của hỗn hợp, tỷ lệ axi1t béo bão hòa càng lớn thì nhiệt độ chuyển trạng thái càng cao và ngược lại (Limbardo \& ctv., 2017). Vì vậy khi thay thế bơ cacao bằng dầu dừa, axit béo không bão hòa tăng lên dẫn đến nhiệt độ chuyển trang thái giảm dần. Khi ở trạng thái lỏng tại nhiệt độ $31^{0} \mathrm{C}$ hay $50^{\circ} \mathrm{C}$, độ nhớt của các hồn hợp giảm mạnh khi thay thế bơ cacao bằng dầu dừa dưới $20 \%$ tổng lượng chất béo, sau đó có xu hướng giảm ít hơn khi tỷ lệ dầu dừa thay thế tăng lên (Hình 6). Sức căng bề mặt của dầu dừa là $33,6 \mathrm{mN} / \mathrm{m}\left(25^{0} \mathrm{C}\right)$ cao hơn của bơ cacao là 14,2 mN/m (Rodrigo \& ctv., 2005), nên khi sức căng bề mặt càng lớn thì khả năng bao phủ bề mặt hạt cacao càng kém, dẫn đến khả năng bao phủ để làm bền hệ của dầu dừa kém hơn bơ cacao (giảm khả năng tương tác giữa các hạt bơ cacao). Do đó cấu trúc hỗn hợp hình thành lỏng lẻo, mất khả năng kháng dòng chảy nên độ nhớt giảm. Tương tự như mẫu $(\mathrm{M})$, kết quả cũng cho thấy rằng độ nhớt của hỗn hợp $(\mathrm{MCO})$ ở nhiệt độ $31^{\circ} \mathrm{C}$ cao hơn so với độ nhớ ở nhiệt độ $50^{\circ} \mathrm{C}$, tuy nhiên không có sự khác biệt lớn do tại những nhiệt độ này tinh thể chất béo hình thành những dạng cấu trúc chung.

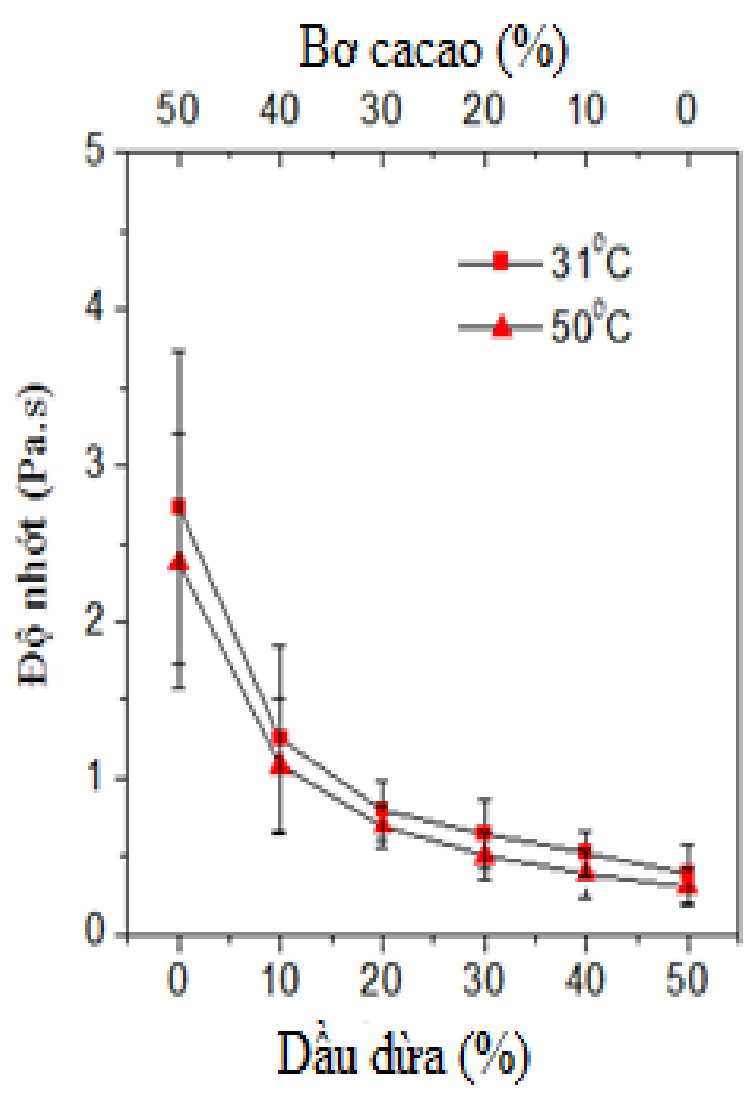

Hình 6. Ảnh hưởng của tỷ lệ bơ cacao/bột cacao/dầu dừa đến độ nhớt.

Trong khi đó, ở trạng thái rắn sự nóng chảy, độ cứng của hỗn hợp mẫu (MCO) có sự phụ thuộc đáng kể của dầu dừa. Tại $5^{0} \mathrm{C}$, mẫu có độ cứng cắt giảm từ $324 \mathrm{~N}$ (mẫu không có dầu dừa) xuống $230 \mathrm{~N}$ khi thay hoàn toàn bơ cacao bằng dầu dừa (mẫu 50\% dầu dừa) (Hình 7a). Tương tự, sự thay đổi ảnh hưởng của dầu dừa đến độ cứng cắt cũng ít hơn tại $10^{\circ} \mathrm{C}$, sự khác biệt giữa hai nhiệt độ này chủ yếu xảy ra tại những hỗn hợp có tỷ lệ bơ cacao cao hơn dầu dừa. Nguyên nhân của sự khác biệt này có thể do ảnh hưởng đồng thời của nhiệt độ cũng như tương tác giữa các hạt cacao (Do \& ctv., 2007). Ở nhiệt độ thấp hơn, lúc này mạng lưới cấu trúc vững chắc được hình thành làm tăng lực khi cắt. Tuy nhiên khi tỷ lệ chất béo (dầu dừa) tăng thì khả năng bao phủ hạt cacao kém hơn do sức căng bề mặt thấp làm ảnh hưởng đến tương tác giữa các hạt cacao. Trong trường hợp này do lượng chất béo đủ lớn $(50 \%)$ làm cho các hạt cacao bị phân tán trong lớp chất béo kết tinh hóa rắn, điều này lý giải tại sao không có sự khác biệt về độ cứng khi ép nén khi thay thế bơ 

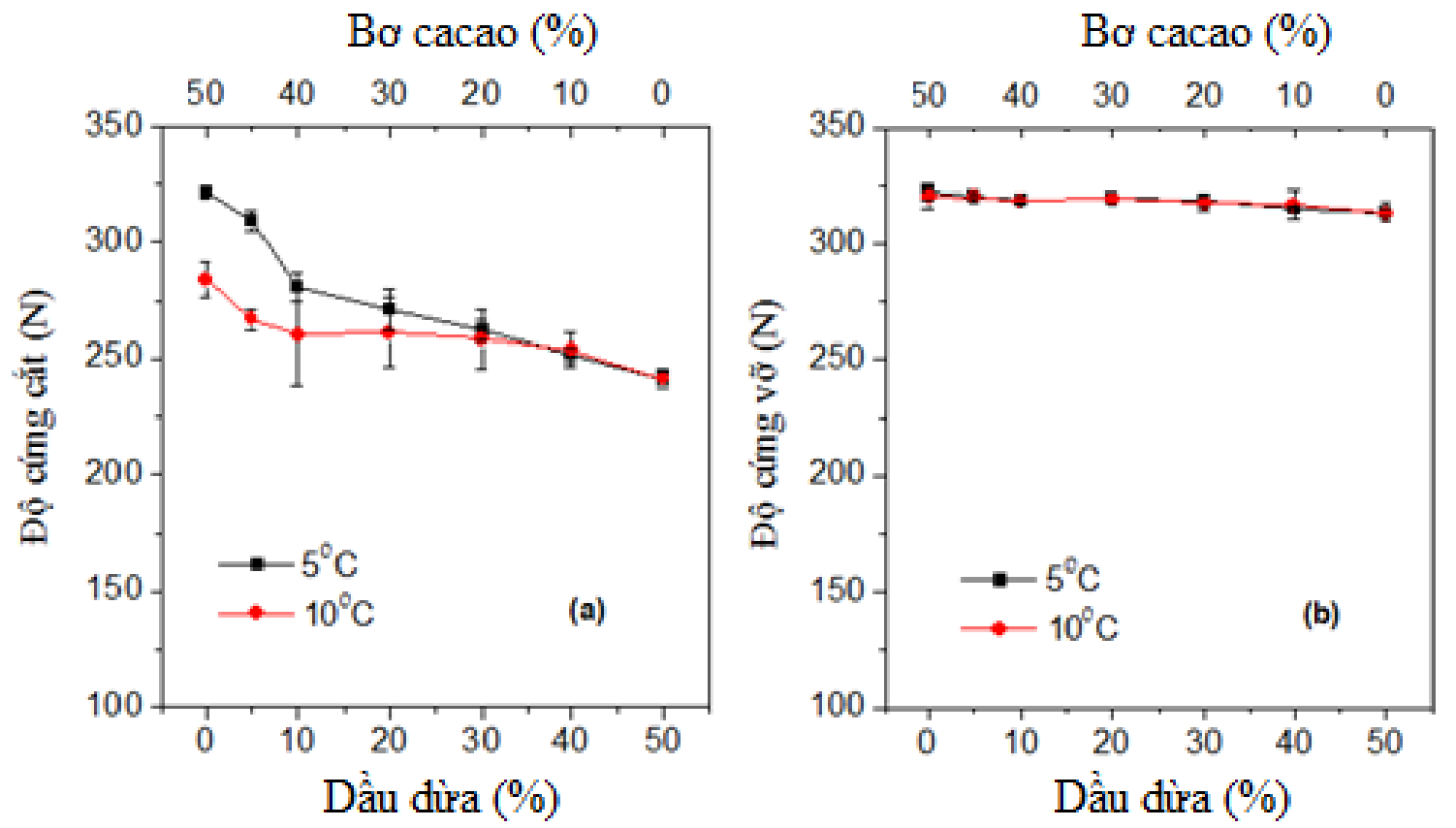

Hình 7. Độ cứng - cắt (a) và độ cứng - vỡ (b) của mẫu $(\mathrm{MCO})$ dày $5 \mathrm{~mm}$.

Bột cacao (\%)

Bột cacao (\%)

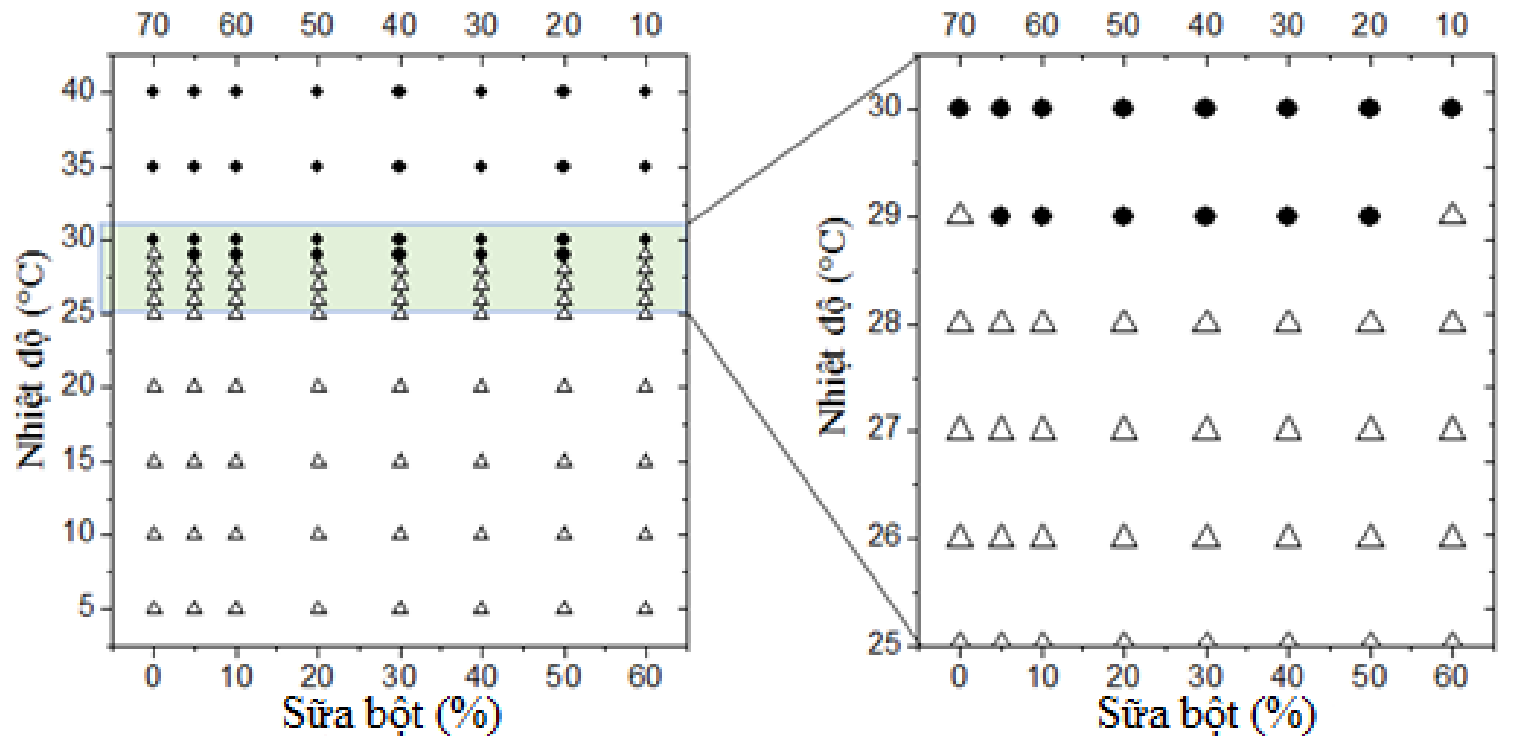

Hình 8. Trạng thái lỏng $(\bullet)$ - rắn $(\Delta)$ của hỗn hợp bơ cacao/bột cacao có bổ sung sữa bột.

cacao bằng dầu dừa là do chúng đã hóa rắn hoàn toàn tại nhiệt độ $5^{0} \mathrm{C}$ và $10^{0} \mathrm{C}($ Hình $7 \mathrm{a}, \mathrm{b})$.

Ảnh hưởng của chiều dày mẫu cũng được khảo sát và kết quả cho thấy với chiều dày $10 \mathrm{~mm}$, ảnh hưởng của tỷ lệ các thành phần chất béo, nhiệt độ cũng có xu hướng biến đổi tương tự như mẫu có chiều dày $5 \mathrm{~mm}$ (kết quả không được trình bày). 


\section{3. Ảnh hưởng của sữa bột đến trạng thái, độ nhớt và độ cứng của hỗn hợp}

Kết quả khảo sát trạng thái mẫu (MMP) cố định $30 \%$ bơ cacao và $70 \%$ còn lại thay đổi tỷ lệ giữa bột cacao và sữa bột theo nhiệt độ được thể hiện trong Hình 8. Nhiệt độ kết tinh hóa rắn của các mẫu thêm sữa bột $\left(28^{\circ} \mathrm{C}\right)$ thấp hơn mẫu $(\mathrm{M})$ $\left(29^{0} \mathrm{C}\right)$ do tạo thành hỗn hợp "eutecti" làm giảm nhiệt độ kết tinh (Awad \& Marangoni, 2006) vì khi bổ sung sữa sẽ làm tăng lượng chất béo trong hỗn hợp, chất béo trong sữa không chỉ bảo vệ sự kết tinh bơ cacao mà còn là tác nhân gây ra sự chuyển đổi cấu trúc dạng $\mathrm{V}$ sang dạng VI của bơ cacao, do đó nó làm thay đổi nhiệt độ kết tinh hóa rắn hay tan chảy của hỗn hợp (Rios \& ctv., 2014).

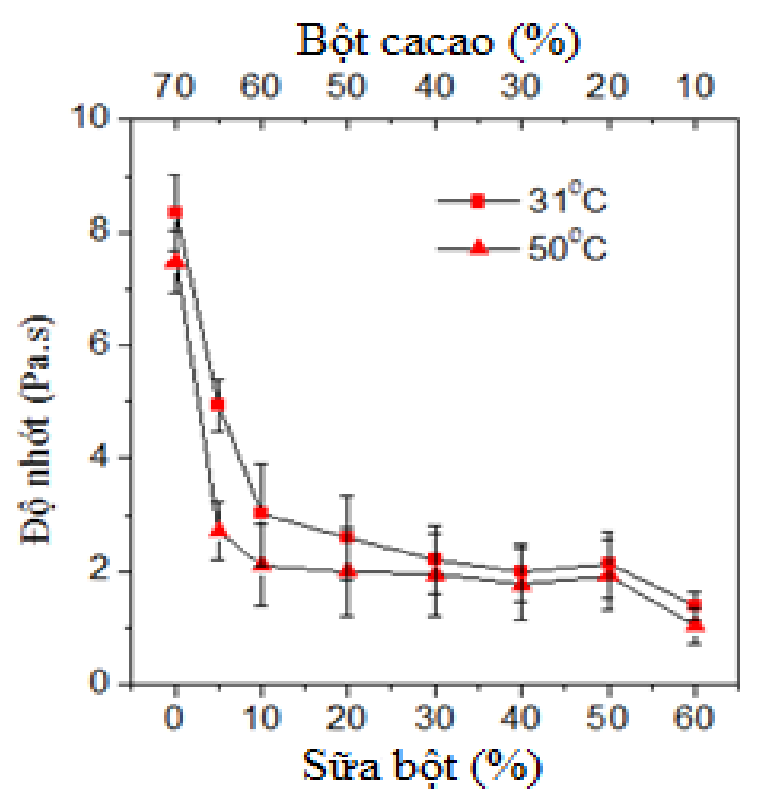

Hình 9. Ảnh hưởng của tỷ lệ bơ cacao/bột cacao/sữa bột đến độ nhớt.

Khi phối trộn sữa bột vào hỗn hợp bơ cacao/bột cacao, sữa bột sẽ tương tác với bơ cacao tạo nên một hỗn hợp chất béo không tương thích hoàn toàn (Chevalley, 1975), hàm lượng chất béo tăng và xảy ra hiệu ứng "eutecti", hình thành một hệ có điểm nóng chảy thấp. Sữa bột bổ sung sẽ làm giảm mạnh độ nhớt hỗn hợp khi hàm lượng sữa bột thêm vào khoảng $10 \%$ và dần ổn định khi hàm lượng sữa bột tăng lên (Hình 9). Theo Glicerina \& ctv., (2016), khi thêm sữa thì hàm lượng chất béo tăng sẽ tăng sự tương tác chất béo - chất béo và làm giảm các thông số lưu biến như độ nhớt, độ cứng (Chevalley, 1975; Awad \& Marangoni, 2006; Glicerina \& ctv., 2016). Hàm lượng sữa bột tăng đồng nghĩa với hàm lượng chất béo tổng số của hỗn hợp tăng trong khi hàm lượng bơ cacao không đổi, dẫn đến lượng chất béo tổng để bao phủ các hạt cacao và sữa tăng, do đó khả năng chống lại dòng chảy giảm - đó là lý do làm cho độ nhớt của hỗn hợp giảm (Glicerina \& ctv., 2016). Mặt khác, do kích thước sữa bột lớn hơn hạt bột cacao, khi đó diện tích bề mặt tiếp xúc giữa các hạt với phần tử chất béo giảm xuống làm độ nhớt giảm (Sokmen \& Gunes, 2006). Từ đó dẫn đến độ nhớt của hỗn hợp (MMP) giảm một cách rõ rệt, càng bổ sung sữa bột thì độ nhớt càng giảm. Điều này phù hợp với nghiên cứu của Ardakani \& ctv. (2014) đã tìm hiểu về dòng chảy mao dẫn của sôcôla sữa. Ardakani đã cho thấy rằng có sự giảm dần độ nhớt ở nhiệt độ $30^{\circ} \mathrm{C}$. Sự giảm dần độ nhớt của sôcôla sữa có thể được giải thích bởi sự gia tăng hàm lượng chất béo do một phần tan chảy của bơ cacao (Ardakani \& ctv., 2014). Tương tự hai mẫu (M) và (MCO), độ nhớt mẫu (MMP) cũng bị tác động bởi nhiệt độ. Theo Briggs \& ctv. (2014) độ nhớt tăng lên đáng kể ở $31^{0} \mathrm{C}$ vì sự hình thành của cấu trúc tinh thể trong quá trình tạo mầm kết tinh (tempering).

Kết quả đo cho thấy đột cứng cắt và vỡ của mẫu dày $5 \mathrm{~mm}$ làm lạnh ở $5^{0} \mathrm{C}$ và $10^{\circ} \mathrm{C}$ tương đương nhau (Hình 10a,b). Mẫu dày $10 \mathrm{~mm}$ cũng được nghiên cứu tương tự, tuy nhiên mẫu này làm lạnh ở $5^{0} \mathrm{C}$ và $10^{\circ} \mathrm{C}$ dều không thể thực hiện được phép đo độ vỡ vì mẫu quá cứng, lực sử dụng trong quá trình đo không đủ để phá vỡ khối mẫu (kêt quả không được trình bày). Khi nhiệt độ làm lạnh hỗn hợp ở $20^{\circ} \mathrm{C}$, ảnh hưởng của sữa bột tỷ lệ nghịch với độ cứng của mẫu.

Ở $20^{\circ} \mathrm{C}$, độ cứng của mẫu giảm khi tăng tỷ lệ sữa bột thay thế bột cacao. Điều này được lý giải là do tỷ lệ chất béo tăng lên bởi lượng chất béo từ sữa bổ sung, đồng thời tỷ lệ các hạt chất rắn giảm đi, dẫn đến các tương tác giữa các chất rắn với nhau yếu đi, khả năng chảy của chất béo tăng lên ở nhiệt độ cao (Glicerina \& ctv., 2016). Cũng theo Glicerina \& ctv. (2016), khi tăng tỷ lệ sữa cũng có nghĩa là giảm lượng năng lượng cần thiết để bắt đầu quá trình chảy của chất béo tại một nhiệt độ đủ lớn. Lúc này cấu trúc của hỗn hợp sẽ lỏng lẻo hơn khi mà lượng sữa bột thay thế bột cacao càng tăng. Ngoài ra, hiệu ứng "eutecti" giữa các chất béo của sữa và bơ cacao cũng là nguyên nhân làm mềm mẫu rắn, độ cứng kém hơn so với mẫu không bổ sung sữa bột. 

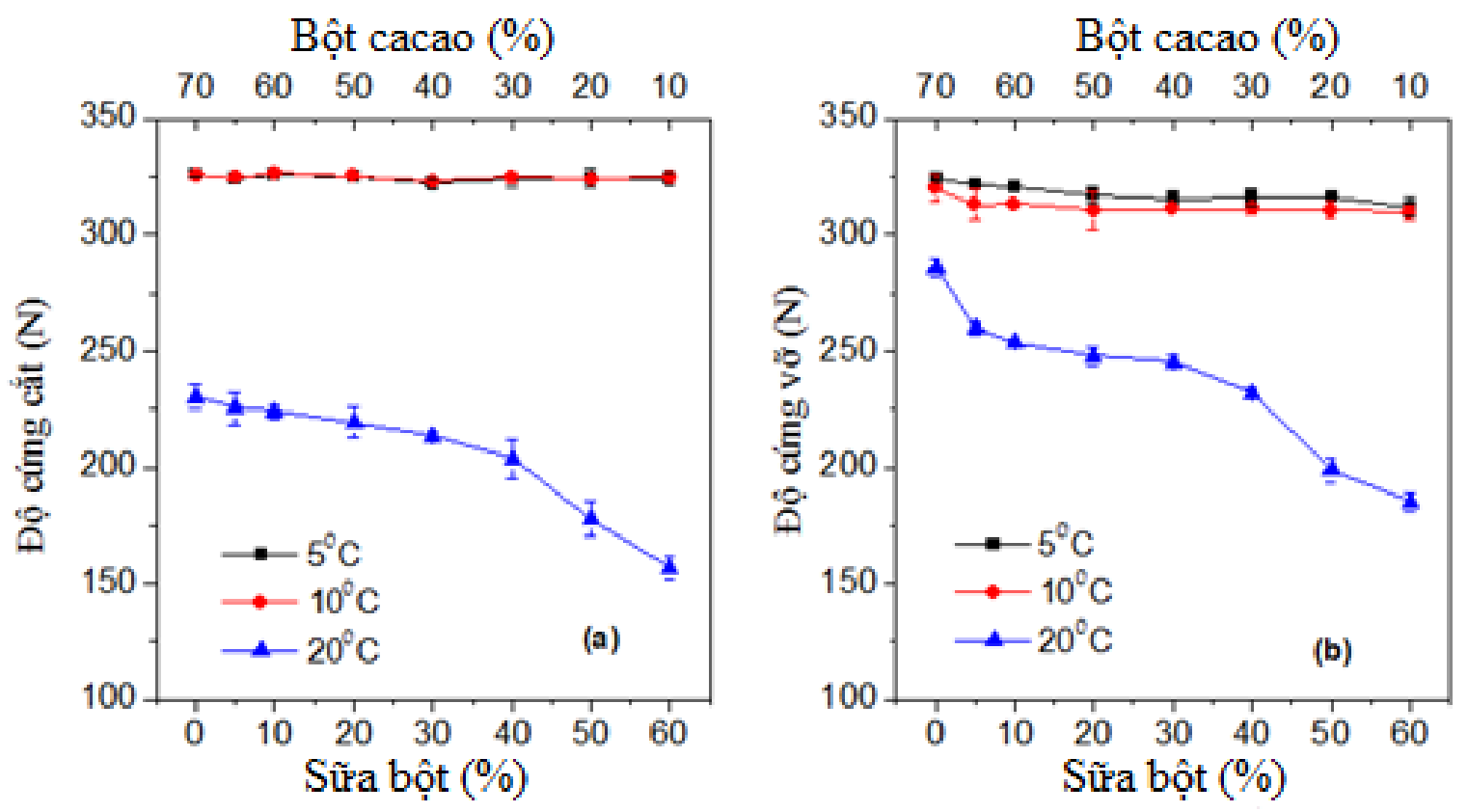

Hình 10. Độ cứng - cắt (a) và độ cứng - vỡ (b) của mẫu (MMP) dày 5 mm.

\section{Kết Luận}

Hỗn hợp bột cacao và bơ cacao có nhiệt độ kết tinh hóa rắn giảm từ $24^{0} \mathrm{C}$ xuống $20^{\circ} \mathrm{C}$ khi tăng tỷ lệ dầu dừa thay thế bơ cacao, đặc biệt xảy ra điểm "eutecti" giữa hai chất béo bơ cacao/dầu dừa làm nhiệt độ kết tinh thấp hơn khi thay thế trên $10 \%$ bơ cacao bằng dầu dừa. Đồng thời hỗn hợp có độ nhớt và độ cứng giảm, sản phẩm có kết cấu mềm mại hơn so với mẫu không bổ sung dầu dừa.

Khi bổ sung sữa bột để thay thế bột cacao, sự kết hợp chất béo của sữa bột và bơ cacao làm nhiệt độ kết tinh giảm nhẹ so với mẫu không có sữa bột. Ở trạng thái lỏng, hỗn hợp có độ nhớt thấp hơn. Độ cứng của khối mẫu bổ sung sữa bột cũng giảm đi, nếu thay thế quá nhiều bột cacao bằng sữa bột sẽ làm cấu trúc của sôcôla không chặt chẽ, khi cắt hoặc làm vỡ xuất hiện nhiều vụn nhỏ do chất rắn không được áo ngoài tốt bởi bơ cacao.

\section{Tài Liệu Tham Khảo (References)}

Ačkar, D., Škrabal, S., Šubarić, D., Babić, J., Miličević, B., \& Jozinović, A. (2015). Rheological properties of milk chocolates as influenced by milk powder type, emulsifier, and cocoa butter equivalent additions. In- ternational Journal of Food Properties 18(7), 15681574 .

Afoakwa, E. O., Paterson, A., \& Fowler, M. (2007). Factors influencing rheological and textural qualities in chocolate - a review. Trends in Food Science and Technology 18(6), 290-298.

Afoakwa, E. O., Paterson, A., Fowler, M., \& Vieira, J. (2009). Microstructure and mechanical properties related to particle size distribution and composition in dark chocolate. International Journal of Food Science and Technology 44, 111-119.

Afoakwa, E. O., Paterson, A., Fowler, M., \& Vieira, J. (2008). Characterization of melting properties in dark chocolates from varying particle size distribution and composition using differential scanning calorimetry. Food Research International 41(7), 751-757.

Ardakani, H. A., Mitsoulis, E., \& Hatzikiriakos, S. G. (2014). Capillary flow of milk chocolate. Journal of Non-Newtonian Fluid Mechanics 210, 56-65.

Awad, T. S., \& Marangoni, A. G. (2006). Ingredient Interactions Affecting Texture and Microstructure of Confectionery Chocolate. In Gaonkar, A. G., \& McPherson, A. ( $2^{\text {nd }}$ ed., 423-476). Ingredient interactions: Effects on Food Quality. Florida, America: CRC Press.

Briggs, J. L., \& Wang, T. (2004). Influence of shearing and time on the rheological properties of milk chocolate during tempering. Journal of the American Oil Chemists' Society 81(2), 117-121.

Chevalley, J. (1975). Rheology of chocolate. Journal of Texture Studies 6, 177-196. 
Do, T. A. L., Hargreaves, J. M., Wolf, B., Hort, J., \& Mitchell, J. R. (2007). Impact of particle size distribution on rheological and textural properties of chocolate models with reduced fat content. Journal of Food Science 72(9), E541-E552.

Full, N. A., Reddy, S. Y., Dimick, P. S., \& Ziegler, G. R. (1996). Physical and sensory properties of milk chocolate formulated with anhydrous milk fat fractions. Journal of Food Science 61(5), 1068-1073.

Gabriele, D., Migliori, M., Baldino, N., \& De Cindio, B. (2008). Influence of fat content on chocolate rheology. AIP Conference Proceedings 1027. Maryland, America: American Institute of Physics.

Gala, U., Pham, H., \& Harsh, C. (2013). Pharmaceutical applications of eutectic mixtures. Journal of Developing Drugs 2(3), e130. doi:10.4172/2329-6631.1000e130.

Gao, X., Guo, T., Han, F., Tian, Y., \& Zhang, Z. (2015). Rheological and sensory properties of four kinds of dark chocolates. American Journal of Analytical Chemistry 6(13), 1010-1018.

Glicerina, V., Balestra, F., Dalla Rosa, M., \& Romani, S. (2016). Microstructural and rheological characteristics of dark, milk and white chocolate: A comparative study. Journal of Food Engineering 169, 165-171.

Mochizuki, Y. (2001). Texture Profile Analysis. Current Protocols in Food Analytical Chemistry 00(1), $\mathrm{H} 2.3 .1-\mathrm{H} 2.3 .7$.
Liang, B., \& Hartel, R. W. (2004). Effects of milk powders in milk chocolate. Journal of Dairy Science 87(1), 2031.

Limbardo, R. P., Santoso, H., \& Witono, J. R. (2017). The effect of coconut oil and palm oil as substituted oils to cocoa butter on chocolate bar texture and melting point. AIP Conference Proceedings 1840 (0600011-060001-12). Maryland, America: American Institute of Physics.

Rios, R. V., Pessanha, M. D. F., Almeida, P. F. de, Viana, C. L., \& Lannes, S. C. da S. (2014). Application of fats in some food products. Food Science and Technology (Campinas) 34(1), 3-15.

Rodrigo, B., Anikumar, G. G., Antonio, B., Ignacio, G. L., David, P., \& Manuel M. (2005). Production of cocoa butter microcapsules using an electrospray process. Journal of Food Science 70(8), 492-497.

Sokmen, A., \& Gunes, G. (2006). Influence of some bulk sweeteners on rheological properties of chocolate. $L W T$ - Food Science and Technology 39(10), 1053-1058.

Timms, R. E. (1980). The phase behaviour of mixtures of cocoa butter and milk fat. Lebensmittel-Wissenschaft und-Technologie 13(2), 61-65. 